\title{
Discipleship and Stewardship: The Essential Combination that Can Enhance Financial Stability of the Church in Africa
}

\author{
Jeremiah Theophilo Izungo ${ }^{1^{*}}$ and Mussa Simon Muneja, ThD ${ }^{2}$ \\ ${ }^{1}$ Adventist University of Africa, Kenya \\ ${ }^{2}$ University of Arusha, Tanzania \\ *Corresponding Mail: izungoj@aua.ac.ke
}

\begin{abstract}
While discipleship and stewardship are essential aspects in Christian life, combination of the two terms can provide financial stability and spiritual growth in the church. This study employed the literary method through the collection of journal articles from America, Europe Asia and Africa with topics which have addressed the two aspects. The findings show that it is important that every church member should surrender his/her life to Jesus before surrendering all that he/she has to Christ. The study recommends that church members must be led to be faithful stewards and faithful disciples by precepts and example. Church leaders and pastors need to call church members to surrender their lives to Christ before calling them to surrender their wealth for supporting the work of God. They should also make calls that church members should not only give tithe and offerings for sustaining the gospel work, but they should also engage themselves in making disciples for Christ.
\end{abstract}

Keywords: Discipleship, stewardship, church, financial stability, small groups, seminars

\section{Introduction}

Financial stability of the Church has been one of needs to sustain the gospel work in the Christian churches. This study sought to explore the uses of the two key terms namely, Discipleship and Stewardship for the purpose of enhancing the financial stability of the church. In the pursuit, the paper reviewed 15 journals article that contain topics that are closely related with the two terms. These journal articles addressed four main continents, namely America, Europe, Asia and Africa. The exploration in these articles involved the summary of the article and the critical assessment of the current situation of churches in Africa. It is the assumption of the paper that without addressing the rising challenge in church finance, the churches in Africa will not prosper and fulfill her mission. It is the impression of the authors that the combination of the two elements will provide the potential expectations and the certainty of funds to ensure the growth and the expansion of the work.

The word disciple is defined as one who embraces and obeys the teachings of Christ and endeavors by word and deed to make others disciples (Watson \&
Watson, 2014). Stewardship is defined as “... a relationship that every person bears to his Creator (Rees, 1982). Steward is "a person who superintends another's affairs, esp. an estate or farm" (Schwarz, 1997). Disciple is "a person who follows or believes in the doctrine of another" (Schwarz, 1997). According to Jesus, one of the key qualification is faithfulness (Luke 12:42). According to Paul, the same requirement is expected of him or her (1 Cor 4:20). All who have been called by God through Jesus, are considered to be faithful stewards of God's grace in its various forms (1Peter 4:10). (NIV) The definitions of these two terms suggest similarities. Both of them connect the person with God. They also show the relationship that a person should have with God. These definitions pave way for a better understanding of this study.

\section{Studies in America}

Raduly (2005) conducted a study to find the causes for the inability to manage financial resources in Roundup - Lewistown, Canada. The cause of this problem was found to be lack of financial literacy. In addressing this issue, both pre-financial literacy 
and post-financial literacy seminars were conducted. The results showed that the intervention was ineffective. Therefore, it was suggested that cognitive information is not enough to change the behavior that is related the finance. Other factors such as more time, personal motivation, etc. are needed. The researcher thought that this subject is crucial because the church members are not able to manage their own money intelligently, then this suggests that it will not be easy for them to return to God what is due to Him faithful.

In a similar vein, Dutra (2005) conducted a study to find why churches are growing numerically rapidly and not in a quality manner, meaning those who are joining the church are not living up to what they claim to believe. It was revealed that there is a lack of discipleship programs. This trend led the church to lose new church members. The literature related to the problem was further reviewed and the program was developed aiming to enable church members to in Brazil to be responsible disciples for Christ. The study epitomizes that the program must begin with the leaders of the church and their families. In other words, leaders must lead by example. This would usher all other church members to come on board. Furthermore, there is an emphasis, which encourages church members take upon themselves their discipleship role and work for the salvation of others; as a result, the church members will strengthen their faith and grow in grace. In other words, there is no better way of helping the new church members than helping the longtime Christian to lead and to live the life of their Master Jesus Christ.

Another study in North America was done by Marquez (2005) who showed that there was a problem among the youth; it was revealed that $60 \%$ of youth were leaving the church. It is believed that the reason for this trend is that, the church lacks an effective discipleship program for the youth. In dealing with the problem, Marquez conducted a Biblical study on Jesus' method of Discipleship. The author used the key elements that Jesus used in making the disciples. There was interview that was taken before the program and after the program. There were seven themes that were addressed during the inventory and these were vision, gospel, surrender, intimacy, witnessing, the body of Christ, and service. The results were positive, in that there was a growth among the youth who were joining and remaining in the church. In reference to this study, it appears that there is no better way of retaining and nurturing the youth than the way that the Lord Jesus Christ used, making them His disciples. Therefore, parents could be the best helpers of Jesus to make their children the Disciples of Christ. The paper has the opinion that parents should teach their children the word of God and this is their God-given responsibility (Deut 6:6, 7).

Osorio (2009) conducted a study in Hoover Hispanic Seventh-day Adventist Church to find what should be done to help the church members and the new converts to a better understanding of the discipleship concept. Osorio used a seminar manual designed for that purpose. The seminar took five days. Two questionnaires were given before and after the program. At the end of the program, participants were able to know the difference between the disciple and the believer. Therefore, it is clearly evident that, when the church members are involved in making other disciples, they will be strengthened themselves in the faith.

A study was conducted by Levy (2020) who revealed that many African American and black communities suffered from financial illiteracy. There are also external challenges and internal challenges that inflicted this community. The four-module financial literacy was designed and implemented in Beth-El Seventh-day Adventist church. The program took four weeks. The program was covered with lectures, small group discussions and homework. Pre and post-survey were administered. It is evident that the study was valuable as it helped people to manage their income intelligently. It is one of the keys subjects that can help to enhance faithful stewards among the church members. Therefore, if church members are to be faithful in their dealing with their own money, that is important background which would enable them to handle God's money the same way.

Kwan (2008) studied to restore St. Clair Evangelical Missionary church to its desirable original state. The institution had lost its spiritual quality of life that is expected of them. Several attempts had failed in the effort to restore it. The study aimed to analyze the situation, determine the actions to help the situation and then implement the program. There are aspects recommended in this program to bring back the situation to its desirable state, namely worship, stewardship, fellowship and discipleship. The key person to work on this plan is the pastor. It was suggested that the pastor will be responsible for discipling the church members and then they will disciple others. This is the only article in this study

152 East African Journal of Education and Social Sciences (EAJESS) 2(3)151-156 
that appears to address discipleship and stewardship together. It is important that pastor should train church members to make disciples within their families and without. This is one of the best ways of not only multiplying the numbers of the disciples but also of strengthening the spirituality of the church members.

\section{Sources in Europe}

Boldeau (2014) conducted a study in the United Kingdom which reveals the challenges that threaten the gospel work. These are celebrities and power seeking, child-sex abuse, spiritual leaders bringing discredit upon their high calling and others. This study aimed to lead pastors and church leaders to follow the example of Jesus by living what they teach and make disciples of all nations. The researcher collected information from 27 pastors. Then two days were set-aside for training sessions for the pastors who would function as mentors. This plan was designed to prepare the young interns to enter into the ministry well prepared and with Confidence. It was pointed out that at the end of the program, all participants who were involved were enriched spiritually from the program. The findings indicate that the long-time committed church members should be prepared to mentor and disciple the new church members. The same can be applied to the experienced pastors and the young pastors.

\section{Sources in Asia}

Kim (2012) conducted a study in the West Central Korea Conference of Seventh-day Adventist Church. The problem was that, the church was failing in the area of discipleship making. The finding showed that the ratio of the church members who are joining the church is the same as those who are leaving the church. Upon these findings, the study aimed at developing the theoretical and practical framework that could help the church to acquire and comprehend the discipleship spirit and takes an active part in leading church members in the right direction. Based on the literature review, a wellplanned discipleship curriculum was introduced that was intended to deepening religious experience and commitment in making disciples. After intervention, there was improvement in member retention. Therefore in referene to this study, Church leadership should prepare and introduce intentional program that must involve both church leaders and church members into the experience of growing in Christ and making the disciples.
Another study was conducted by Kim (2016) in South Korea which revealed that weekly Sabbath school programs lacked the essential elements that can qualify it to be what it was designed for discipleship-making agent. It was suggested that the church leadership should develop and launch a program that will enable church members to become fully committed to Christ's Disciples. It was further suggested that the best place to introduce and practice the Discipleship program is in the Sabbath school. In accordance to this study, it was evident that Sabbath school program is the right place to introduce the discipleship program. Furthermore, it appears that all church departments should plan to make sure that their day-to-day program should be combined closely with the plan of discipleship making. This is because discipleship making is the very work that Jesus Christ did and then commanded all his faithful followers to do. Discipleship making should therefore be the central core of every church department and the work of everyone who accepts Christ as a personal Savior.

On a similar note, Ryu (2014) conducted a study in Osaka Central Seventh-day Adventist church, Japan. The study was based on equipping church membership for contextualized discipleship in the country. The problem was declining of the church caused by failure of the church and its message in connection with Japanese culture. In meeting the objective, discipleship seminars were conducted. Ten selected 'disciple,' were commissioned to go into the community and serve for six months. Moreover, church members were divided into small groups for studying the word and supporting the work of the ten disciples. This culminated in inviting their family members and friends for church services. The results indicated an improvement of church membership. Therefore, the gospel of Jesus Christ must be presented in the context of the people. In making the disciples of all nations, one must study the context of the people and then introduce the gospel in a way that people will understand and accept the gospel in their context.

\section{Sources in Africa}

Adonu (2004) conducted a study in South Ghana. The study aimed to investigate the reasons to poor financial strength in the churches. The methodology used to address the issues was first to study the History of the church at the South Ghana Conference and Ghana's giving patterns and then to conduct stewardship seminars among the church members. It was suggested that the solution to the 
challenge was to conduct steward seminars on spirituality and teaching church members how they should give themselves to God and then give what they have to support the work of God. It is prudent, therefore, to lead church members to know Jesus Christ and His will in their lives before calling them to surrender their lives and their wealth under His feet.

A study conducted in Malawi by Masoka (2006) revealed that there is a lack of well-planned training for the church members. Church members were perceived to depend entirely on pastors and church leadership for their spiritual nourishment than helping themselves. In the conclusion, the author opted to launch the intentional discipleship program for the church members. The study advised that the best way to strengthen the church members for their growth and spiritual wellness is to connect them with the Lord Jesus Christ. It is through Him and by His grace that they can bear fruits (John 15:7, 8; Math. 28:19-20) and then to involve them in ministering to each other. In this manner, the church members will keep up their spiritual strength and at the same time be used to strengthen others and fulfill their God given responsibility as $\mathrm{His}$ disciples.

Another study was conducted in South Africa by Misiani (2006). It aimed to discover a model that one could use to develop an authentic discipling community in context of South Africa. The study arranged that participants meet in small groups for a period of 16 hours. The Bible study was designed to lead the participants to walk with God. The program was successful because members became active in inviting many community members to be followers of Christ. Therefore, small groups are one of the key factors that can be used to lead church members into a meaningful Bible study and lead participants to be disciples of Christ.

Munyumbwe (2012) conducted a study in Zambia with the aim to determine the stability rate of ushering new members to the church and equipping new church members to grow and to maintain their spiritual life. The author conducted several weeks of prayer and house-to-house visitations. This resulted into more new members residing in the church than going away through the back door. Before sending them to the world, Jesus Christ trained the disciples and then they were ready to be sent (Math. 28:19, 20). The preachers, church leaders and church members should therefore follow Christ's example in teaching, visiting and making disciples. This is the best way of achieving the best results in enabling both new and old church members to grow spiritually. It is essential that church leaders and church members should always live what they claim to believe and live what they teach. Living contrary to one's teaching is contrary to Christ's dogma (Math 23:3).

Furthermore, Bichang'a (2014) conducted a study in Kenya with the aim of measuring the behavior of returning tithe and giving offerings faithfully to God. The study used church treasurer's reports and conference reports to analyze the situation and the depth of the challenge; thereafter seminars and house-to-house visitations were conducted for the church members to achieve the goal of being faithful in returning tithes and offerings. The seminars were successful and members began returning tithe and offerings. The paper concurs that, sermons, lecturing and seminars are good, but if visitation is missing, the work is half done. Visitation enables the pastor to address the different issues closely and in a clearer manner than in public. Visitation is therefore a crucial aspect in nurturing and leading church members to be faithful stewards. It is the opinion of the researchers that that visitation alone cannot accomplish much. Therefore, there is a need of connecting visitation with discipleship programs to bring a lasting impact

\section{Analysis and Findings}

The analysis shows that the definitions of the terms discipleship and stewardship as used in this study suggest similarities. Both require faithfulness and both present the kind of relationship that should exist between God and man. Both convey some kind of the responsibilities that one should bear as he/she works with God and man. The analysis of the literature shows that, as far as the discipleship is concerned, it is necessary that both new and old church members be involved in making the disciples for Christ for their spiritual growth and for the salvation of others. The findings have also revealed that disciples need to be connected with Jesus Christ that they may live His lives and His teachings so that they will be able to make others disciples. It is Jesus Christ who empowers them to do what is expected of them (John 15:5).

On stewardship, it has been revealed that before leading church members to surrender their wealth to Christ, they should be lead to surrender their lives to Christ. It has been also revealed that such aspects as visitation, seminars and other stewardship 
programs are essentials. However, these aspects should be accompanied with discipleship making for best results. It has further revealed that the knowledge of managing personal finance intelligently will pave way for church members to handle properly funds that belongs to God. The paper suggests that leaders and church members need to combine the two aspects in their lives: to be faithful Disciples of Christ and faithful stewards of God. The combination of the two can enhance the stability of the church. In the work of leading church members to be both faithful disciples and faithful stewards, church leaders and pastors must do so by precepts and example following closely the examples of Jesus Christ.

\section{Conclusions and Recommendations}

The paper has presented two aspects: Discipleship and stewardship as essential Christian aspects, which should exist in the life of every Christian believer. The paper has attempted to highlight the necessity of combining the two aspects for the purpose of enhancing financial stability of the church so as to advance the gospel work efficiently. Most of the studies that have been presented dealt with one aspect at a time. The combination of the two can help to increase both faithful disciple makers and funds that are needed in God's work. It is Jesus's command that His disciples should go and make disciples (Math. 28:19-20). Now, according to Paul, going demands that somebody should be sent (Rom 10:15), but also those who minister are to be taken care of (1 Cor 9:13). This is a call for the two items to be combined.

The study recommends that church members must be led to be faithful stewards and faithful disciples by precepts and examples. Leaders must do what they expect church members to do. Church leaders and pastors need to call church members to surrender their lives to Christ before calling them to surrender their wealth for supporting the work of God. Church leaders and pastors should always make calls that church members should not only give tithe and offerings for sustaining the gospel work, but they should also engage themselves in making disciples for Christ.

\section{References}

Adonu, A. K., (2004). Promoting Financial and Spiritual Growth in the Seventh-day Adventist Churches in the South Ghana Conference through Stewardship Workshops. A doctoral Dissertation from
Andrews University, USA. Retrieved from https://digitalcommons.andre ws.ed u/dmin/559.

Bichang'a, J. M. (2014). A Strategy to Increase Giving in the South Kenya Conference. A doctoral Dissertation from Andrews University, USA. Retrieved from https://digitalcommons.andrews.edu/dmin/ 261

Boldeau, D. G. (2014). Developing a Mentoring Model, Based on Christ's Approach to Discipleship, for Intern Pastors in the British Union. A doctoral Dissertation from Andrews University. https://digitalcommons .andrews.edu/dmin/18

Coleman, M. G. (2018). A Strategy for Discipleship of New Members at the Mount of Olives Seventh-Day Adventist Church. A doctoral Dissertation from Andrews University, USA. Retrieved from https://digitalcommons.andrews.edu/dmi $\mathrm{n} / 671$

Dutra, A. E. (2005). A Discipleship Model for Evangelism in Notheast Brazil. A doctoral Dissertation from Andrews University, USA. Retrieved fromhttps://digitalcommons.an drews.edu/dmin/467

Kim, S. (2016). Developing the Educating for Discipleship Model to be used in Sabbath School in South Korea. A doctoral Dissertation from Andrews University, USA. Retrieved from https://digitalcomm ons.andre ws.edu/dmin/292

Kim, S. J. (2012). Development a Discipleship Ministry for Seventh-day Adventist Churches in the West Central Korean Conference. A doctoral Dissertation from Andrews University, USA. Retrieved fromhttps://digitalcommons.and rews .edu $/ d \min / 292$

Knowles, W. R. (2015). A Discipleship Project for New Members at the St. John's Seventh-day Adventist Church. https://digitalcommons. and rews.edu/dmin/286A doctoral Dissertation from Andrews University, USA. 
Kwan, E. (2008). A Strategy for Revitalization St. Clair EMC through Authentic Practice of Worship,Stewardship, Fellowship and Discipleship. A doctoral Dissertation from Andrews University, USA. Retrieved from https://digitalcommons.fuller.e $\mathrm{du} / \mathrm{dmin} / 10$

Levy, T. S. (2020). A Strategy for Increasing the Level of Financial Literacy Among African Americans in the Greenville Neighborhood of Jersey City, Nj. A doctoral Dissertation from Andrews University, USA. Retrieved from https://digitalcommons. Andre ws.edu/dmin/718

Marquez, D. M. (2005). A Discipleship Model for Youth at the Paradise Adventist Church. A doctoral Dissertation from Andrews University, USA. Retrieved from https ://digitalcommons.andrews.edu/dmin/348

Masoka, W. L. (2006). A Biblicallly Based Strategy for Discipleship Making in the Seventh-day Adventist Church Plant in Johannesburg. . A doctoral Dissertation from Andrews University, USA. Retrieved fromhttps:/ /digitalcommons.andrews.edu/dmin/642

Misiani, S. O. (2006). A Discipleship Program for Developing Community in the Amazing Grace Seveth-day Adventist Church Plant in Johannesburg. A doctoral Dissertation from Andrews University, USA. Retrieved fromhttps://digitalcommons.andrews.e $\mathrm{du} / \mathrm{dmin} / 496$

Munyumbwe, V. M. (2012). A Discpling Strategy for Mult-Church District in Zambia. A doctoral
Dissertation from Andrews University, USA. Retrievedfromhttps://digitalcommons .andrews.edu/dmin/89

Osorio, E. (2009). A Discipleship Model "Go and Make Disciples" for the Hispanic Hoover Seventh Day Adventist Church in alabama. A doctoral Dissertation from Andrews University, USA. Retrieved from https://digitalcommons.andrews.edu/dmin/ 582

Raduly, A. (2005). A Biblical Training Model to Improve the Financial Literacy of the Members of the Roundup=lewistown. A doctoral Dissertation from Andrews University, USA. Retrieved fromhttps :/ /digitalcomm ons.andrews.edu/dmin/439

Rees, M. (1982). God and Man Unlimited. Washington D.C:: Review and Herald Publishing Association.

Ryu, J. H. (2014). Equipping Church Members for Contexualized Discipleship in Osaka Central Seventhd-day Adventist church, West Conference, Japan. A doctoral Dissertation from Andrews University, USA. Retrieved from https://digitalcommons.andrews.edu/dmin/ 582

Schwarz, C. (1997). Chambers Concise Dictionary. 77 7 Hopetown Crescent, Chamber Harrap Publishers Ltd.

Watson, D. L., \& Watson, P. D. (2014). Contagious Discipleship Making . Nashville: TN: Thomas Nelson. 